\title{
BEHAVIORAL CHANGES IN Rattus norvegicus EXPERIMENTALLY INFECTED BY Toxocara canis LARVAE
}

Pedro P. CHIEFfi(1,2), Renata T.R. AQUINO(1), Maria A. PASQUALOTTI(1), Manoel Carlos S.A. RIBEIRO(1) \& Antonia G. NASELLO(1)

\begin{abstract}
SUMMARY
Toxocara canis is a common canine nematode parasite and one of its possible transmission mechanisms is the predation of infected rodents by canids. Fifty Rattus norvegicus were used to study behavioral alterations in rodents infected by $T$. canis larvae. The rats were divided into three groups: G1, 20 rats infected with 300 T. canis eggs; G2, 20 rats infected with 2,000 T. canis eggs; and G3, 10 non-infected rats. Thirty and 60 days post-infection, rats from all the groups were submitted to an open-field apparatus for five min and subsequently, to an elevated plus-maze apparatus, again for five min. The data obtained indicated improvement in mobility (total locomotion time and rearing frequency) and exploratory behavior in infected rats, principally in G2, which provides some support for the hypothesis that behavioral alterations in rodents infected by Toxocara canis larvae enhance the transmission rate of this ascarid to dogs.
\end{abstract}

KEYWORDS: Toxocara canis; Rattus norvegicus; Behavioral alterations; Open-field apparatus; Elevated plus-maze apparatus.

\section{INTRODUCTION}

Toxocara canis is a common canine helminth parasite belonging to the Ascaridae family. Humans and several other vertebrates, usually small in size, can be infected by T. canis larvae and act as paratenic hosts, without developing adult intestinal worms, while harboring viable third stage larvae in their tissues or organs for long periods. In humans, the infection by Toxocara larvae has a cosmopolitan distribution and may occasionally result in the occurrence of visceral or ocular larva migrans syndrome $\mathrm{e}^{1,14,16}$.

The infection of dogs by $T$. canis occurs by several mechanisms, including the predation of paratenic hosts. CHIEFFI et al. $(1981)^{4}$ observed the frequent presence of anti-Toxocara antibodies at significant levels in Rattus norvegicus trapped in the municipality of São Paulo, Brazil, suggesting their role as paratenic hosts for this ascarid.

Some authors have reported behavioral alterations and learning impairment in mice infected by $T$. canis larvae $2,6,7,8,9,10$. Recently, one study reported diminished muscular strength in $R$. norvegicus experimentally infected by $T$. canis larvae, suggesting some enhancement of the preypredation mechanisms of infection ${ }^{3}$.

The aim of the present paper was to investigate whether experimental infections of Rattus norvegicus by different levels of Toxocara canis third stage larvae result in behavioral alterations that facilitate rodent predation by canids.

\section{MATERIAL AND METHODS}

Fifty Wistar strain female $R$. norvegicus, aged 6-8 weeks-old, were divided into three groups; G1, 20 rats infected by 300 T. canis eggs; G2, 20 rats infected with 2,000 T. canis eggs; and G3, 10 non-infected rats. Using an esophageal catheter, the rats were orally infected with a solution of $T$. canis eggs obtained after dissection of female worms and maintained at least 30 days in a $2 \%$ solution of formalin at $28^{\circ} \mathrm{C}$. Before inoculation, the eggs were carefully washed three times with distilled water. The control group rats (G3) only received distilled water.

Rat behavior was verified by means of open field and elevated plusmaze apparatus on two occasions, 30 and 60 days post-infection. On the day of the behavioral tests, the rats were placed in the experimental room at least four hours beforehand.

Open-field behavior: Spontaneous motor activity was monitored for five min in an open-field, as previously described ${ }^{13}$. The structure consisted of a circular arena composed of a hardboard floor $(99 \mathrm{~cm}$ in diameter) with a surrounding wall $(30 \mathrm{~cm}$ in height), both made of white colored wood. The floor was divided into 46 parts using circles and radial segments. The apparatus was placed in a sound-attenuated room, $48 \mathrm{~cm}$ above the floor. At the onset of testing, the rats were individually placed in the center of the arena and the following parameters were recorded: total locomotion (TL: number of floor units entered); locomotion in central squares (CL); rearing frequency (number of times the rat stood on its hind legs); defecation units (number of fecal boli); immobility and grooming

(1) Faculdade de Ciências Médicas da Santa Casa de São Paulo. São Paulo, SP, Brasil.

(2) Instituto de Medicina Tropical de São Paulo (LIM 06). São`Paulo, SP, Brasil.

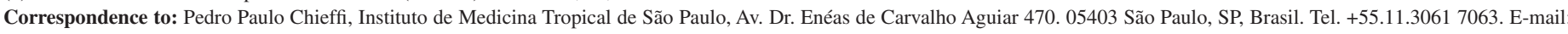
pchieffi@usp.br 
CHIEFFI, P.P.; AQUINO, R.T.R.; PASQUALOTTI, M.A.; RIBEIRO, M.C.S.A. \& NASELLO, A.G. - Behavioral changes in Rattus norvegicus experimentally infected by Toxocara canis larvae. Rev. Inst. Med. Trop. Sao Paulo, 52(5): 243-6, 2010.

duration. Before introducing each rat into the arena, it was washed with $5 \%$ alcohol to eliminate possible bias due to odors left by the previous subject. Besides motor activity, this test permits the measurement of anxiety, detected by diminished central locomotion, a greater number of fecal boli and the time spent in grooming activity.

Elevated plus-maze (EPM) behavior: Immediately after the openfield test, a five min EPM test was performed, as previously described ${ }^{13}$. The apparatus consists of a wooden plus-maze elevated $50 \mathrm{~cm}$ from the floor and comprising two opposite open arms, $50 \mathrm{x} 10 \mathrm{~cm}$, crossed at right angles by two arms of the same dimensions enclosed by $40 \mathrm{~cm}$ high walls, with no roof. The maze was placed inside a sound-attenuated room. The rats were initially placed onto the center platform of the maze facing an open arm. The following parameters were recorded: the total number of entries (TE) into any of the arms; number of entries into open (EOA) and closed arms (ECA); percentage of entries into open arms; time spent in the open arms (TOA) and percentage of time spent in the open arms. This apparatus was also thoroughly cleaned between subjects. This test is based in the natural aversion of rodents to open spaces, which directly confronts their interest in exploring their surroundings. It permits the measurement of anxiety through this fear-exploration paradigm, such that an increase in the open field parameters denotes decreased anxiety.
After day 60 post-infection, all the rats were sacrificed and T. canis larvae were recovered from the liver, lungs, brain, kidneys and muscles after digestion with $0.5 \% \mathrm{HCl}$ for 24 hours at $37{ }^{\circ} \mathrm{C}$, according to the technique described by XI \& JIN (1998) ${ }^{19}$. Throughout the entire experiment, rats were housed in special cages submitted to a $12 \mathrm{~h}$ lightdark cycle, with food and water ad libitum.

Statistical analysis: The data were analyzed by analysis of variance (ANOVA), using SPSS-15 and comparing the results separately at each moment. Post Hoc tests were also made comparing the groups two by two, using Bonferroni's multiple comparisons adjustments, in the data related to time. Results related to number of events were analyzed by Kruskal-Wallis and Mann-Whitney tests. In all performed tests the level of significance was established at $\mathrm{p}<0.05$.

\section{RESULTS}

The data obtained in the open-field apparatus for $R$. norvegicus 30 and 60 days after $T$. canis infection are summarized in Tables 1 and 2.

The results obtained when the rats were submitted to the elevated plus-maze apparatus are summarized in the Tables 3 and 4.

Table 1

Behavioral parameters obtained in the open-field apparatus for Rattus norvegicus experimentally infected with either 300 or 2,000 Toxocara canis eggs, 30 days postinfection

\begin{tabular}{|c|c|c|c|c|c|c|}
\hline \multirow[t]{2}{*}{ Parameters } & \multicolumn{2}{|c|}{ Control } & \multicolumn{2}{|c|}{300 eggs } & \multicolumn{2}{|c|}{2,000 eggs } \\
\hline & $\mathrm{Am}$ & (SD) & $\mathrm{Am}$ & (SD) & $\mathrm{Am}$ & $(\mathrm{SD})$ \\
\hline Total locomotion* & 80.6 & $(35.1)^{* * *}$ & 110.0 & $(17.5)$ & 149.9 & $(46.1)^{* * *}$ \\
\hline Central square locomotion* & 10.3 & $(6.5)$ & 13.0 & (12.7) & 16.4 & $(8.7)$ \\
\hline Immobility* & 195.0 & $(46.1)^{* * *}$ & 154.2 & $(28.6)$ & 128.3 & $(44.7)^{* * *}$ \\
\hline Grooming* & 5.4 & (7.2) & 10.0 & $(10.8)$ & 10.1 & $(9.9)$ \\
\hline Rearing frequency** & 10.3 & $(5.9)^{* * *}$ & 10.8 & $(4.2)$ & 23.4 & $(12.5)^{* * *}$ \\
\hline Defecation $* *$ & 3.7 & $(2.5)$ & 3.8 & $(2.2)$ & 2.0 & $(1.9)$ \\
\hline
\end{tabular}

$\mathrm{Am}=$ arithmetic mean; $\mathrm{SD}=$ standard deviation; $*$ measured in seconds; $* *$ number of times, $* * * \mathrm{p}<0.05$.

Table 2

Behavioral parameters obtained in the open-field apparatus for Rattus norvegicus experimentally infected with either 300 or 2,000 Toxocara canis eggs, 60 days postinfection

\begin{tabular}{|c|c|c|c|c|c|c|}
\hline \multirow[t]{2}{*}{ Parameters } & \multicolumn{2}{|c|}{ Control } & \multicolumn{2}{|c|}{300 eggs } & \multicolumn{2}{|c|}{2,000 eggs } \\
\hline & Am & (SD) & Am & (SD) & Am & (SD) \\
\hline Total locomotion* & 95.2 & $(48.6)$ & 112.2 & $(43.7)$ & 102.8 & $(40.4)$ \\
\hline Central square locomotion* & 9.0 & $(6.1)^{* * *}$ & 20.1 & $(13.8)^{* * *}$ & 12.1 & $(6.7)$ \\
\hline Immobility* & 167.6 & $(39.8)$ & 142.0 & $(37.7)$ & 151.6 & $(58.8)$ \\
\hline Grooming* & 16.2 & $(16.5)$ & 14.2 & $(8.1)$ & 17.9 & (12.3) \\
\hline Rearing frequency** & 9.8 & $(8.4)$ & 15.6 & $(12.1)$ & 10.5 & $(9.9)$ \\
\hline Defecation $* *$ & 6.1 & $(3.6)$ & 4.1 & $(2.7)$ & 4.9 & $(1.7)$ \\
\hline
\end{tabular}

$\mathrm{Am}=$ arithmetic mean; $\mathrm{SD}=$ standard deviation; $*$ measured in seconds; $* *$ number of times; $* * * \mathrm{p}<0.05$. 
CHIEFFI, P.P.; AQUINO, R.T.R.; PASQUALOTTI, M.A.; RIBEIRO, M.C.S.A. \& NASELLO, A.G. - Behavioral changes in Rattus norvegicus experimentally infected by Toxocara canis larvae. Rev. Inst. Med. Trop. Sao Paulo, 52(5): 243-6, 2010.

Table 3

Behavioral parameters obtained in the elevated plus-maze apparatus for Rattus norvegicus experimentally infected with either 300 or 2,000 eggs, 30 days postinfection

\begin{tabular}{lcccccc}
\hline Parameters & \multicolumn{2}{c}{ Control } & \multicolumn{2}{c}{300 eggs } & \multicolumn{2}{c}{2,000 eggs } \\
\cline { 2 - 7 } & Am & (SD) & Am & (SD) & Am & (SD) \\
\hline Entries in open arms* & 3.2 & $(1.9)$ & 4.0 & $(2.4)$ & 5.0 & $(2.2)$ \\
Entries in closed arms* & 2.4 & $(2.4)^{* * *}$ & 2.0 & $(0.8)$ & 4.1 & $(2.0)^{* * * *}$ \\
Time in open arms** & 46.1 & $(31.3)$ & 85.8 & $(90.1)$ & 49.4 & $(20.9)$ \\
Time in closed arms** & 236.4 & $(46.4)$ & 188.4 & $(94.2)$ & 219.6 & $(30.7)$ \\
Bottom open arms* & 0.9 & $(0.7)$ & 1.6 & $(1.1)$ & 1.5 & $(1.1)$ \\
Bottom closed arms* & 2.4 & $(2.2)^{* * *}$ & 6.0 & $(2.7) * * *$ & 9.1 & $(3.9)^{* * * *}$ \\
Head dipping* & 5.0 & $(2.4)$ & 5.0 & $(2.7)$ & 5.0 & $(3.0)$ \\
\hline
\end{tabular}

$\mathrm{Am}=$ arithmetic mean; $\mathrm{SD}=$ standard deviation; *number of times, **measured in seconds, $* * * \mathrm{p}<0.05$.

Table 4

Behavioral parameters obtained in the elevated plus-maze apparatus for Rattus norvegicus experimentally infected with either 300 or 2,000 eggs, 60 days postinfection

\begin{tabular}{lcccccc}
\hline Parameters & \multicolumn{2}{c}{ Control } & \multicolumn{3}{c}{300 eggs } & \multicolumn{2}{c}{2,000 eggs } \\
\cline { 2 - 7 } & Am & (SD) & Am & (SD) & Am & (SD) \\
\hline Entries in open arms* & 3.1 & $(1.6)$ & 4.3 & $(2.3)$ & 3.0 & $(1.2)$ \\
Entries in closed arms* & 2.0 & $(1.1)$ & 3.1 & $(1.9)$ & 2.2 & $(1.6)$ \\
Time in open arms** & 29.8 & $(8.5)$ & 53.4 & $(40.8)$ & 30.1 & $(16.1)$ \\
Time in closed arms** & 240.4 & $(58.8)$ & 210.0 & $(63.1)$ & 243.4 & $(32.9)$ \\
Bottom open arms* & 1.2 & $(0.9)$ & 1.9 & $(1.5)$ & 0.9 & $(0.9)$ \\
Bottom closed arms* & 1.8 & $(1.1)^{* * *}$ & 7.4 & $(3.8)^{* * *}$ & 5.2 & $(2.7)^{* * *}$ \\
Head dipping* & 2.1 & $(1.9)$ & 3.7 & $(2.8)$ & 2.2 & $(1.3)$ \\
\hline
\end{tabular}

$\mathrm{Am}=$ arithmetic mean; $\mathrm{SD}=$ standard deviation; $*$ number of times, $* *$ measured in seconds, $* * * \mathrm{p}<0.05$.

After rats sacrificing the average number of Toxocara canis larvae recovered by tissue digestion in the group infected with 300 eggs was $117( \pm 15.2)$ and $781( \pm 68.1)$ in the group inoculated with 2,000 eggs.

\section{DISCUSSION}

In the last two or three decades, researchers have became increasingly interested in studying behavioral alterations in parasitized hosts and whether such alterations represent adaptive alterations in order to enhance parasite transmission. In a critical review of the evidence of adaptive alterations in host/parasite behavior, POULIN (1995) ${ }^{15}$ highlighted the fact that some of these behavioral alterations could be non-adaptive, that they were side-effects of the infection. Either way, even nonadaptive behavioral alterations could be considered to enhance parasite transmission rate under certain circumstances.

While observing alterations in the behavior of certain infected hosts and parasites during their life cycle, COMBES $(2001)^{5}$ denominated as favorization, the adaptive process that modifies the temporal and spatial disposition of parasites and their hosts, resulting in improvement in the transmission rate. Numerous reports describe behavioral changes associated with parasitic infections that facilitate the transmission from intermediate or paratenic hosts to the definitive host, principally when prey-predator interaction is involved as a transmission mechanism ${ }^{5}$. For example, several studies have shown the ability of Toxoplasma gondii tachy or bradyzoites to manipulate the behavior of rodents, making them more subject to predation by cats ${ }^{17,18}$.

A similar situation could be proposed for the relationship between $T$. canis larvae, rodents and dogs and some authors have actually verified the occurrence of behavioral alterations in mice infected by larvae of this ascarid $^{2,6,7,8,9,10}$, though not as clearly as has been demonstrated for the interaction between Toxoplasma gondii and rodents. Moreover, the great majority of papers on this issue used mice and not Rattus norvegicus. On the other hand, Rattus norvegicus trapped in the municipality of São Paulo (São Paulo State, Brazil) showed anti-Toxocara antibodies in significant levels ${ }^{4}$, suggesting its possible role as paratenic hosts for Toxocara canis.

The results of the present paper, associated with recent research published by CHIEFFI et al. (2009) ${ }^{3}$, provide some support to the 
CHIEFFI, P.P.; AQUINO, R.T.R.; PASQUALOTTI, M.A.; RIBEIRO, M.C.S.A. \& NASELLO, A.G. - Behavioral changes in Rattus norvegicus experimentally infected by Toxocara canis larvae. Rev. Inst. Med. Trop. Sao Paulo, 52(5): 243-6, 2010.

hypothesis that the interaction between $T$. canis, rodents and dogs suffers manipulation in order to enhance the transmission rate of this ascarid via a prey-predator relationship. Thus, as presented in Table 1 , analysis of the data revealed an improvement in the mobility (total locomotion time and rearing frequency) of rats 30 days after infection with 2,000 eggs of $T$. canis and, consequently, in the rats' environmental exploratory behavior. In contrast, rats infected with 300 eggs revealed a tendency for greater mobility compared to non-infected rats, though this was not statistically significant. Precisely 30 days post-infection with 300 T. canis eggs, CHIEFFI et al. (2009) ${ }^{3}$ observed significant impairment in the rats' muscular strength. The improvement in mobility and exploratory behavior, together with muscular strength impairment, are special circumstances that could readily enhance the transmission rate of $T$. canis by predation of rodent paratenic hosts. As shown in Table 2, 60 days after $T$. canis infection, improvement in mobility is not so clear, suggesting that the behavioral alterations are not permanent. Working with the Toxoplasma gondii-mouse model HRDÁ et al. $(2000)^{12}$ also concluded that the observed behavioral changes were transient and disappeared prior to week 12 post-inoculation.

The data obtained in the elevated plus-maze apparatus (Tables 3 and 4), on the other hand, suggest that $T$. canis infected mice did not show a tendency to remain in the open arm of the maze, indicating the development of a higher degree of anxiety and the search for greater protection both at 30 and 60 days post-infection. Nevertheless, the results verified in the elevated plus-maze apparatus, the improvement in mobility and exploratory behavior associated with the muscular strength impairment observed in rats after 30 days of infection by T. canis larvae ${ }^{3}$ indicate the possible occurrence of transient manipulation of rodent behavior, which could result in the enhancement of the transmission rate of this ascarid by prey-predation interactions.

\section{RESUMO}

\section{Alterações de comportamento em Rattus norvegicus experimentalmente infectados por larvas de Toxocara canis}

Toxocara canis é um nematódeo parasita habitual do intestino delgado de cães. Um dos mecanismos conhecidos de transmissão para cães é representado pela predação de pequenos roedores que, como hospedeiros paratênicos albergam larvas de Toxocara canis em seus tecidos. Para avaliar a ocorrência de alterações de comportamento em roedores infectados por Toxocara canis 50 exemplares de Rattus norvegicus foram utilizados no experimento. Os animais foram divididos em três grupos: G1 - 20 ratos infectados com 300 ovos de Toxocara canis; G2 - 20 ratos infectados com 2.000 ovos de Toxocara canis e G3 - 10 ratos sem infecção. Trinta e 60 dias após a infecção avaliou-se a ocorrência de alterações comportamentais nos três grupos submetendo os animais, primeiramente, a uma arena de campo aberto durante cinco minutos e, a seguir, a labirinto em cruz elevado por mais cinco minutos. Os resultados obtidos indicaram aumento significativo da mobilidade (tempo total de movimentação e número de vezes em que os animais se levantaram nas patas traseiras) e comportamento exploratório nos ratos infectados, principalmente nos pertencentes ao G2, sugerindo a ocorrência de alterações comportamentais que favoreceriam a transmissão de Toxocara canis para canídeos por meio de relação presa-predador.

\section{REFERENCES}

1. Barriga OO. A critical look at the importance, prevalence and control of toxocariasis and the possibilities of immunological control. Vet Parasitol. 1988;29:195-234.

2. Burright RG, Donovick PJ, Dolinsky ZS, Hurd Y, Cypess R. Behavioral changes in mice infected with Toxocara canis. J Toxicol Environ Health. 1982;10:621-6.

3. Chieffi PP, Aquino RTR, Paschoalotti MA, Ribeiro MCSA, Nasello AG. Muscular strength decrease in Rattus norvegicus experimentally infected by Toxocara canis. Rev Inst Med Trop Sao Paulo. 2009;51:73-5.

4. Chieffi PP, Del Guercio VMF, Ueda M, Mello LB. Importância de Rattus norvegicus capturados no município de São Paulo, SP, Brasil como hospedeiros paratênicos de Toxocara canis (Ascaroidea, Nematoda). Rev Inst Adolfo Lutz. 1981;41:89-91.

5. Combes C. Parasitism. Chicago: University of Chicago Press; 2001.

6. Cox DM, Holland CV. The relationship between numbers of larvae recovered from the brain of Toxocara canis-infected mice and social behaviour and anxiety in the host. Parasitology. 1998;116:579-94.

7. Cox DM, Holland CV. Relationship between three intensity levels of Toxocara canis larvae in the brain and effects on exploration, anxiety, learning and memory in the murine host. J Helminthol. 2001;75:33-41.

8. Donovick PJ, Burright RG. The consequences of parasitic infections for the behavior of the mammalian host. Environ Health Perspect. 1987;73:247-50.

9. Donovick PJ, Dolinsky ZS, Perdue VP, Burright RG, Summers B, Cypess RH. Toxocara canis and lead alter consummatory behavior in mice. Brain Res Bull. 1981;7:317-23.

10. Hamilton CM, Stafford P, Pinelli E, Holland CV. A murine model for cerebral toxocariasis: characterization of host susceptibility and behavior. Parasitology. 2006;132:791-801.

11. Hay J, Arnott MA, Aitken PP, Kendall AT. Experimental toxocariasis and hyperactivity in mice. Z Parasitenkd. 1986;72:115-20.

12. Hrdá S, Votýpka J, Kodym P, Flegr J. Transient nature of Toxoplasma gondii-induced behavioral changes in mice. J Parasitol. 2000;86:657-63.

13. Nasello AG, Machado C, Bastos JF, Felício LF. Sudden darkness induces a high activity -low anxiety state in male and female rats. Physiol Behav. 1998;63:451-4.

14. Overgaauw PAM. Aspects of Toxocara epidemiology: toxocarosis in dogs and cats. Crit Rev Microbiol. 1997;23:233-51

15. Poulin R. "Adaptive" changes in the behaviour of parasitized animals: a critical review. Int J Parasitol. 1995;25:1371-83.

16. Schantz PM. Toxocara larva migrans now. Am J Trop Med Hyg. 1989;41(Suppl 3):21-34.

17. Webster JP. Rats, cats, people and parasites: the impact of latent toxoplasmosis on behaviour. Microbes Infect. 2001;3:1037-45.

18. Webster JP. The effect of Toxoplasma gondii on animal behavior: playing cat and mouse. Schizophr Bull. 2007;33:752-6.

19. Xi WG, Jin LZ. A novel method for the recovery of Toxocara canis in mice. J Helminthol. 1998;72:183-4.

Received: 29 April 2010

Accepted: 25/8/2010 